\title{
Does epilepsy increase the risk of needing to return to the hospital due to mood disorders?
}

Matthew McCaskill, DO

Neurology ${ }^{\circledR}$ 2018;91:e890-e893. doi:10.1212/WNL.0000000000006092

Those living with epilepsy face many challenges every day. Mood disorders such as depression, bipolar disorder, and posttraumatic stress disorder (PTSD) are on the rise in the United States.

In "Increased risk of hospital admission for mood disorders following admission for epilepsy," $\mathrm{Kim}^{1}$ examined how epilepsy may contribute to people returning to the hospital with psychiatric issues after previous admission for epilepsy.

Even if a patient's seizures are controlled, clinicians can better give advice to patients and their families about the risk of mood disorders resulting in return trips to the hospital. This includes paying attention to issues that may lead to hospital readmission.

\section{How was the study done?}

$\mathrm{Kim}^{1}$ used the Nationwide Readmissions Database (NRD) to study if epilepsy hospital admissions, compared to admissions for other medical causes, are associated with a higher readmission risk for mood disorders. The NRD captured data from about 15 million hospital discharges, or nearly half of US hospitalizations in 2013.

Authors studied adults from 30 to 85 years old. They did not include children. The epilepsy group of 58,278 people was compared to a group of 215,821 people who were admitted to the hospital for stroke. They also studied 973,078 people who were admitted to the hospital for common illnesses, such as pneumonia, urinary tract infection, congestive heart failure, or chronic obstructive pulmonary disorder. About half of the patients were women.

The researchers used a standard coding system to identify medical conditions that increased the risk of hospital readmission. This is a system of unique codes used to describe why patients need to be seen by a doctor. The researchers were careful to only use codes specific for epilepsy to identify that group. They were more liberal with the inclusion of various mood disorders since those diagnoses are less standardized and several different codes may be used to document why patients end up coming to the hospital.

The researchers used this information to study readmission rates at 30, 60, and 90 days. They determined how often patients were admitted for the "index" cause (such as epilepsy, stroke, or other medical conditions). Then for each of these, they determined the risk of being readmitted for a mood disorder.

\section{What were the results?}

The main finding was that those with epilepsy were nearly twice as likely to be readmitted to the hospital within 1 year for a mood disorder (depression or bipolar disorder) than patients with stroke or common medical illnesses. In addition, compared to stroke and medical admissions, the average age of patients admitted for epilepsy was younger. 
It should be noted that epilepsy is not the only medical condition that increases the risk of returning to the hospital due to mood disorders. Other risks for readmission for depression in all groups included known psychiatric problems, substance abuse, or tobacco use at the time of first admission.

The authors also found that there was higher rate of substance use and psychiatric issues at first admission. The most common psychiatric problem was depression. Not surprisingly, there was a higher rate of cardiovascular risk factors in the stroke and medical groups (including high blood pressure, high cholesterol, diabetes, peripheral vascular disease, irregular heart rhythms, and heart attacks).

\section{What does it mean?}

The authors found that people admitted to the hospital for epilepsy had a higher risk of later hospital readmission for mood disorders. This increased risk of readmission for mood disorders following an epilepsy admission illustrates that epilepsy is more than just seizures. It also suggests that hospital admissions are a particularly vulnerable time for these patients. Because this risk of readmission is so high, doctors may want to reconsider how epilepsy admissions are handled. It might be helpful to screen for psychiatric disease during the epilepsy admission. Further research is needed to assess the effect of these risk factors on hospital readmission for mood disorder. We also need to better establish that screening for psychiatric disease is effective in reducing readmission risk. 


\section{About epilepsy}

Steven Karceski, MD

Neurology ${ }^{\circledR}$ 2018;91:e890-e893. doi:10.1212/WNL.0000000000006092

Adapted from: Karceski S. Epilepsy and risk of injury. Neurology 2018;90:e820-e822.

\section{What is a seizure?}

Nerve cells talk to each other constantly. They send both electrical and chemical messages. The chemical messengers are called neurotransmitters. Sometimes, brain cells send the wrong messages. Our brains have their own autocorrect, but just like a cell phone, sometimes an error goes through. When the wrong signal is sent, other brain cells respond to the error by sending abnormal signals. If enough brain cells start sending the same wrong message, a seizure occurs.

One way to think of this is that the brain works like an orchestra. There are different sections in an orchestra, each with its own instruments. Although each instrument plays its own part, it is only when they all play together that complex music is made. While playing, each member of the orchestra has to listen to the other members. As a team, playing together and listening to one another, the best music is made. In other words, when all of the brain cells are working together, a person can think clearly and logically.

However, what if one person in the orchestra began playing a different tune? At first, no one would notice that someone was playing the wrong tune. Nearby orchestra members would become confused: which tune were they supposed to play? As more members of the orchestra began playing the different tune, it would eventually become noticeable. At some point, the different tune might become louder than the original music.

This is similar to how a seizure gets started, and keeps going. The nearby brain cells start playing the wrong tune. They encourage other brain cells to do the same thing. Eventually, 2 different tunes are being played at the same time. For an orchestra, the combined music would be confusing and might turn into noise instead of music. When a person has a seizure, at some point, the seizure is loud enough that he or she can no longer think clearly and logically. If this worsens, a person can no longer stay aware of what is going on. It is at this point that he or she loses consciousness.

\section{What is epilepsy?}

Epilepsy is diagnosed in a person who has had 2 or more unprovoked seizures in his or her lifetime. There are many kinds of seizures. There are many kinds of epilepsy. Using medical tests in combination with a detailed medical history and examination, a doctor can narrow down the list of possibilities to arrive at the correct epilepsy diagnosis.

\section{How is epilepsy diagnosed?}

The doctor will need to know as much as possible about what happened immediately before, during, and after the seizure. How often do the seizures occur? Is there a warning sign? Does the person remember anything about the seizure? All of these questions help the doctor to better understand the kind of seizures and the kind of epilepsy that the person is experiencing. In addition, asking someone who has seen the person's seizures to describe them can provide valuable information. For instance, if the person who had the seizure cannot remember the seizure, the observer may be able to provide information that the patient may not know.

Medical testing can also help to better understand a person's seizures. EEG is a simple and painless study that records the brain's electrical activity. The brain waves are picked up by tiny 
electrodes that are applied to the to the person's scalp. The EEG is reviewed, looking for specific brain wave patterns that happen during or between seizures in patients with epilepsy. These patterns provide critical information about the person's epilepsy, and help with the diagnosis.

Brain imaging studies are critical in understanding the cause of a person's seizures. The 2 most common studies are MRI and CT. Modern CT and MRI provide very detailed pictures of the brain, and are critical in locating tumors, scars, or other abnormalities that may cause seizures.

\section{How are seizures treated?}

There are many treatments for seizures. Medicines are tried first. If these do not work, a doctor may consider special diets, brain surgery, or devices for the treatment of seizures. The physician tries to stop all seizures while causing no side effects. It is important to tell the doctor about problems experienced while on a medication (or any treatment). Together, the patient and doctor will make the best choice of treatments.

\section{Additional resources}

Brain \& Life

brainandlife.org/

\section{Epilepsy Foundation}

epilepsy.com

\section{Citizens United for Research in Epilepsy}

CUREepilepsy.org

\section{Reference}

1. Kim AM. Increased risk of hospital admission for mood disorders following admission for epilepsy. Neurology 2018;91:e800-e810. 


\section{Neurology}

\section{Does epilepsy increase the risk of needing to return to the hospital due to mood disorders? \\ Matthew McCaskill and Steven Karceski \\ Neurology 2018;91;e890-e893 \\ DOI 10.1212/WNL.0000000000006092}

This information is current as of August 27, 2018

\section{Updated Information \& Services}

References

Permissions \& Licensing

Reprints including high resolution figures, can be found at: http://n.neurology.org/content/91/9/e890.full

This article cites 1 articles, 1 of which you can access for free at: http://n.neurology.org/content/91/9/e890.full\#ref-list-1

Information about reproducing this article in parts (figures,tables) or in its entirety can be found online at:

http://www.neurology.org/about/about_the_journal\#permissions

Information about ordering reprints can be found online: http://n.neurology.org/subscribers/advertise

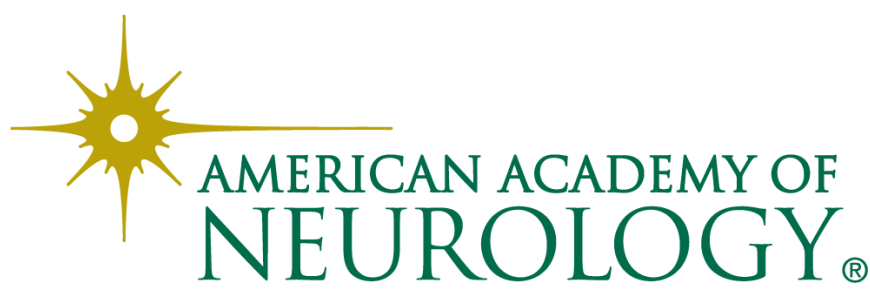

